\title{
Theoretical Approaches to the Study of Life Activity of the Ethnic Group
}

\author{
Oksana A. I'iashevich* \\ Khabarovsk State Institute of Culture \\ 112 Krasnorechenskaia Str., Khabarovsk, 680045, Russia
}

Received 24.11.2015, received in revised form 07.02.2016, accepted 18.04.2016

In this article the author examines the lifeactivity of the ethnic group as a special category in modern culturological and ethnological sciences. The author understands the life activity of such a social community as an ethnic group as a socio-technological complex of cultural processes, which aims at maintaining the relative integrity, bonds within the community, as well as the desirable change and transformation of sociocultural space in the interests of the functioning of thecommunity. The analysis of different approaches to the definition of theessential identity of the ethnic group and ethnic culture allows the author to consider the life activity of the ethnic group as a set of processes that ensure the vitality and highly adaptive and creative potential of ethnic culture. The basis of the life activity of the ethnic group is the continuity of the cultural tradition, which is especially significant for determining the nature of the interaction with the natural environment.

Keywords: ethnic group, life activity, subsistence, lifestyle, ethnic mentality, ethnic culture.

DOI: 10.17516/1997-1370-2016-9-6-1287-1294.

Research area: culture studies.

The functioning of the ethnic group as a special social community is carried out in various areas of social and cultural reality, and is defined as the life activity of the ethnic group.

It is necessary to distinguish the concepts of life activity, which describes the functioning of any social community, and the life activity of the ethnic group.The life activity of the social community is a socio-technological complex of cultural processes, which aims at maintaining the relative integrity, bonds within the community, as well as the desirable change and transformation of sociocultural space in the interests of the functioning of the community.
While studying the life activity of social communities, the following interrelated spheres of the analysis can be distinguished:

1. The sphere of spiritual activity;

2. The economic sphere;

3. The sphere of social services;

4. The environmental sphere;

5. The legal sphere;

6. The political sphere;

7. The organizational sphere.

The abovespheres of socio-cultural scientific researches of life activity are relevant in the study of the functioning of ethnic communities as well. However, the most important spherein

(C) Siberian Federal University. All rights reserved

* Corresponding author E-mail address: oks4132@yandex.ru 
the study of the life activity of the ethnic groupis the sphere of everyday life, everyday culture, not directly connected with a specialized activity and its results. Traditional components of everyday culture reflect the most characteristic features of the ethnic group. They are developed and implemented directly, without specially organized efforts; they are the basis of a lifestyle (a way of life activity organization) of the ethnic group.

The problems of the research of the lifestyle in social and cultural anthropology in domestic science have been repeatedly touched, for example, in many works by E.A.Orlova, where the mechanisms of the development of social and cultural environment by people, creation and change of cultural phenomena in the course of everyday life, are studied (Orlova, 2002: 104).

The concept of "lifestyle" allows detecting a set of socially significant conditions and processes of human activity and assessing the real picture of the socio-cultural dynamics. Lifestyle is a kind of dynamic sociocultural portrait of the members of society, represented through the processes of their life activity in certain conditions, integrity, possessing a cultural sense and caused by the human capacity for productive activity. The form of the lifestyle is determined by the way in whichpeople organize the content of their life activity; in other words, they organizethe processes of activity, behavior and interaction in various spheres of culture. Lifestyle is a category observed in displayedfeatures. It is possible to judge about all the components of the lifestyle of people and the way of their organization by observing the processes of activity, behavior, interaction, communication or their results. The components of the objective conditions that determine the content and form of the lifestyle of people are observable (directly or indirectly) too (Orlova, 2002: 60).

The content of the lifestyle of people is realized in sociocultural spheres, and is defined by two significant groups of factors and conditions, objective and subjective. The objective conditions and factors differentiating the lifestyle of people in a particular historical periodare divided as follows:

- Natural (geographic, climatic, ecological, biological, demographic, etc.);

- Social (the nature of the division of labor and its conditions, social structure and stratification of society);

- Cultural (the amount of cultural information and its distribution over the areas and levels of culture, the structure of sociocultural norms and values acting here, namely economic, social, political, ideological, cognitive, ethical, aesthetic, and other values and norms (Orlova, 2002: 104). The intersection of these groups of conditions and factors that determine the social and cultural life of people, determines the specific historical spheres of realization of their lifestyle. The structure of the lifestyle of people is a relatively stable combination of environments and activities over time in which they participate. These environments and activities as structural components of the lifestylealso serve the individual as the institutional framework that enables him to survive his personal experience in the specific circumstances of life as a socially and culturally important integrity (Orlova, 2002: 74).

The following components can be identified in the living environment of the ethnic group:

1. Natural environment (climate, landscape);

2. Sociocultural environment (as a result of human adaptation to nature and society).

Social structures, cultural and natural environment are the conditions of life activityin which people realize their needs and interests in a certain way. In other words, there is a direct and inverse relationship between the conditions of life activity of people, their needs and interests and the forms of implementation of the latter. Natural, 
social and cultural conditions have a fundamental formative influence on how people organizea variety of their life manifestations. They provide and limit specific historical opportunities of a choice of forms of the individual's self-realization in social and cultural life.

The natural environment is a prerequisite for the emergence and functioning of the ethnic group, and its changes have a significant impact on the ethnic processes. The ethnic group adapts to a particular landscape, at the time of its formation. And if there are changes in the environment, the ethnic group looks for a natural environment, similar to the one in which it was formed. In the history of each ethnic group there is an evidence of a significant impact of the geographical environment on it. The relationship of the ethnic group with the natural environment is implemented through business activities. Ethnic groups living in the Far East, the North and Siberia, leading the assigning lifestyle, fitted into the landscape and did not try to change it. The communication of the ethnic groupand the inclosing landscape emerges in the adaptation of the ethnic collective and its business activities to certain conditions. The ratio of ethnos - landscape fixedover time has become the best for them.

A sustainable landscape stabilizes an ethnic group;therefore there are no compelling reasons for creating a new ethnic group. With the change in the landscape as a result of abrupt climate, the ethnos begins to lose its stability. This leads to the reduction in size and migration of the ethnic group in search of the usual habitat. With regard to the process of ethnogenesis, it occurs without the involvement of climate changes, but the starting points of these processes occur in certain areas of the Earth.

The point of view of L.N. Gumilev on the problem ofthe ethnic group's habitat seems to be interesting. "The geographical terrain affects the organism by force, makingall individuals vary in a certain direction, to the extent permitted bythe organization of species. Tundra, forest, steppe, desert, mountains, water environment, life on the islands, and others, together put a special mark on organisms. Those species, which are not able to adapt, must die out or move to a different geographic landscape" (Gumilev, 1994: 638).

Geographical environment has a major impact on the ethnic group (especially in the early stages of social development) during the period of its formation and adaptation to the environment. The natural environment is a natural place for the location of production, the source and condition of human economic activity, and the totality of natural resources forms (natural) environmental potential of economic development of the ethnic group. At the same time the natural environment performs an essential non-productivefunction, being the physical environment of people, a source of recreation and creativity. Such static components as the surrounding landscape, terrain, some outstanding objects of nature, as well as the dynamic ones such as natural disasters, atmospheric and hydrosphere processes (storm, hurricane, tsunami, etc.) make up the foundation, from which the content of myths and fairy tales, ethnic archetypes and poetic imagesis drawn.

The objects of the influence of the environment can be found in many different areas of ethnic culture.They are tools, household items, ethnonyms. The climate, for example, defines the characteristics of clothing in many ways. In the Far East, the North and Siberia the harsh climate in winter and subtropical climate in summer led to the production of seasonal clothing and shoes, summer and winter homes. The nature of the terrain, rivers, lakes, mountains, forests and seas affect the work and the type of settlements (Podmaskin, 1990: 60).

The characteristic features of the geographical environment (climate, soil texture, topography, flora and fauna) also have 
an impact on certain aspects of the spiritual life and psyche of the ethnic group. Indirectly, this is reflected in the habits, customs, rituals, which manifest the features of everyday life of the people associated with the condition of their habitat. For example, the physical education of theOrochis is subject to the preparation of traditional work. The toughening up of children as an important element of this process began even before their birth. A semi-nomadic way of life of the family formed a child's high resistance to cold, unsettled life, irregular meals, and other adverse natural environmental factors since the first days of life. Ignoring pain, cold and hunger was the result of such a habit (Istoriiaikul'turaorochei, 2001: 54).

The geographical environment is reflected in ethnic self-consciousness. The landscapes of an ethnic territory are imprinted in the minds of the ethnic group as representations of their native land. The influence of the geographical environment on ethnic identity can be seen in the names of peoples and ethnic groups. For example, the Orochis call themselves "orochon" (having deer) (Arsen'ev, 1909: 209).

The main condition of the life activity of the ethnic group in many scientific studies is traditional environmental management, preservation of the connectionwith a specific geographical landscape. L.N.Gumilev called such a landscape "nourishing". Accordingly, the relationship of ethnicity and landscape iscalled “ethnocoenosis" (Gumilev, 1994: 267). In modern conditions theethnocoenosis of indigenous peoples of the Far East, the North and Siberia are spatially aligned with the ethnocoenosisof the dominant society. As a result, they lostthe system independence and integrity.

The ethnoeconomicsystem is a part of ethnocoenosis. The area, which is formed by the system, even after the destruction, is called anethnoeconomic area.
The parameters of the ethnoeconomic system are derived from the following factors:

1. Cultural and ethnic (language, cultural identity, family ties within the ethnos)

2. Environmental (a feature of the environment, availability of biological resources, the effect of the nourishing landscape).

3. Socio-economic (the interaction of an indigenous ethnic group with a dominant society). (Chesnov, 1998: 400)

The ethnos habitat is not only the natural environment, butthe socio-cultural environment, a part of which are economic and cultural styles and historical types of culture.

The main task of the life activity of the ethnic group is to ensure the quality of the environment as the basic condition for the functioning of ethnic culture. The main tasks of the life activity of the ethnic group are related to the confrontationofthe inertia of regressive dynamics of the habitat, supplying the life-creative potential of ethnic culture.

The life activity of the ethnic group is defined as a set of cultural and social processes, which reflects the specificity of the system organization of the ethnic group and provides the life-creative potential of ethnic culture in situations of greater or lesser transformations of ethnos habitats.

The specificity of the life activity of the ethnic group is determined by a combination of living conditions (ethnoshabitat) and the focusof the ethnos subsistence caused by its adaptive strategies. The concept of subsistence, associated with the functioning of the ethnic group, is widely used by ethnographers, anthropologists, historians, sociologists and cultural specialists.

The term of subsistence was proposed by the American ethnographer R. Loewy and means the technologyof obtaining and production of food. In the Russian science, the term has a broader interpretation. In the opinion of I.I.Krupnik (Krupnik, 1998), the 
concept of zhizneobespechenie (subsistence translator's note) can be largely regarded as an original Russian-language derivation. This is a figurative translation of the English word subsistence (which isexistence, food, means of sustaining life). It is obvious that subsistence is broader and conceptually richer than existence, let alone food. Based on the successful term, new derivative categories appeared. One of the brightest innovations was the concept of the culture of subsistence as a special component of ethnic culture. This is an integrated set of features of industrial activity, demographic structure, resettlement, labor cooperation, traditions of consumption and distribution, i.e., environmentrelated forms of social behavior, which take care of the existence of the human collective due to the resources of a specific habitat.

Thus, the culture of subsistence is a process of ecological adaptation of society to the natural environment. We will consider where and when the subsistence of the ethnos takes place in space, which is expressed in the relationship society nature and society - the individual.The cycle of the development of the natural environment takes place in the pre-defined socio-organized forms.

Since culture is a way of human activity, the material technology of societyis its versatile technological subsystem that is closely associated with the social technology of society, and hence with the methods of organization of social relations and socially needed regulation of individuals' behaviour. We will call it a social and technological complex of culture. It consists of dual means of ensuring a specific (the one that is historically and ethnically defined) method of internal organization of public life.

The first group of means includes a set of social institutions (division of labor, property, kinship, marriage, public administration), whichis turned to a social group, and its challenge is to organize inter-relationships.
Another group of meansis "humanitarian"; they are directed to the formation of certain socially appropriate motivations of human activity. The object of their regulatory impact is the sphere of human consciousness that is a set of norms and values and philosophical ideas, as well asethical, etiquette, religious and aesthetic notions. This also includes a range of mechanisms, which are specific to ethnocultural community, namely the ways (technologies) of implementation of these spiritual formations of collective consciousness in the minds of individuals (technologies related to learning, education, upbringing, social control, socialization and so on).

The organization of collective life happens due to the functioning of the internal, ideological and psychological preconditions of human activity. Any spiritual formation, the fact of the collective consciousness is a component of the social technology of societywhich is involved in the maintenance and reproduction of the social mechanism. The functionofthe compensation of stress factorsis also very important. They can be devastating in terms of the psychological unity of the social group. These functions perform the symbolic actions related to subsistence practice (Jung, 1991: 94). The higher the level of anxiety of the ethnic group and the reduction of reliability degree is, the more space the symbolic actions aimed at creating the illusion of countering take.

The system of the ethnos subsistencedepends on the psychological adaptation of man and human society in general. In this context, the adaptation is considered as a process of adaptation of not only to the natural environment but also to the social sphere ofintersocietal (tribal, international, etc.) connections and interactions considered in terms of the activities of a society with which they (the members of the society) come into contact through institutionalized peaceful (diplomatic, trade and others) and military means (Markarian, 1983: 36). 
Thus, the psychological adaptation leads to the fact that subsistence includes both rational and irrational elements, such as the rituals, legends, the specific elements of ideology. The human psyche has delicate regulatory and compensatory properties due to which the establishment of both a direct communication and a feedback from the environment takes place. Once this communication is broken, a violation of the ecological balance happens.

According to E.S.Markarian, the achievement of certain objectives in the processes of the individual's activities that have an adaptive value for it can play a destructive role for the appropriate group and vice versa (Markarian, 1983: 36). The adaptation to the individual's environment and the adaptation of the society may not always coincide. The option to adapt to the environment would be the best for the community in terms of its survival and development, but not suitable for specific individuals in this group. In the opinion of I.I.Krupnik, the apparent stability for the cultures of the peoples of the North manifested itself in "losses and permanent ruptures in the economic and cultural continuity" (Krupnik, 1998: 231).

As a result of environmental and sociocultural adaptation, the ethnic mentality is formed (Pushkarev, 1995: 159). Mentality is a relatively coherent set of ideas, beliefs, views, which creates the worldview and strengthens the unity of the cultural tradition. Mentality characterizes the specific levels of individual and collective consciousness, being a special type of thinking. It is born from the natural groundsand socially caused components and reveals the human representation of the life-world; it expresses habits, predilections, collective emotional patterns. Mentality dates back to the unconscious. It allows combining analytical thinking, advanced forms of consciousness with half-conscious cultural ciphers (Jung, 1991: 94). The nature of mentality is influenced by traditions, culture, social structure, the unconscious, the whole habitat.

The state of the ethnic mentality is affected by a number of factors, both natural and social, which are bound in the ethnic gene pool and are manifested in the features of collective psyche. Among them are the geographical environment, the specificity of economic activities, the pace and way of life, psychoenergyfeatures of the ethnic group, passionarity (Gumilev, 1994: 267), social history, the specificity of intersubjective communications, including language, the features of the spiritual life, including religion, the best type of self-regulation of community, etc. Separating the called determinants of ethnic mentality, it should be emphasized that none of them individually or they all together are able to determine the specificity of the ethnic perception of the world, if they are considered outside the process of human communication (Reshetov, 1983: 12-14).

So, the analysis of different approaches to the definition of the essential identity of the ethnic group and ethnic culture allows us to consider the life activity of the ethnic group as a set of processes that ensure the vitality andhighly adaptive and creative potential of ethnic culture. The basis of the life activity of the ethnic group is the continuity of the cultural traditionthat is especially significant for determining the nature of the interaction with the natural environment. The traditional environmental management is in close correlation with economic development, environmental culture and national consciousness. The clash of industrial civilization with a traditional form of the life activity of indigenous ethnic groups leads to crises and contradictions.

In modern conditions, when the traditional society is opposed to the market society with its inherent features,such as social heterogeneity, the lack of a universal algorithm, which performs the 
control of behavior, the development of science, innovation, there is a need in the creation of the theory of modernization, which would help traditional ethnic groups to define the strategy of life activity and subsistence, and engage in the market society with minimal losses.

\section{References}

Arsen'ev, V.K. (1909). Orochi (orochony). Iz putevogodnevnika [The Orochis. From the notes of a journey], In Pravoslavnyi blagovestnik [Orthodox Evangelizer], 17, 209-218.

Chesnov, Ia.V. (1998). Lektsii po istoricheskoi etnologii: ucheb. posobie [Lectures on Historical Ethnology. Study Guide]. Moscow, Gardarika, 400.

Gumilev, L.N. (1994). Eetnogenez i biosfera Zemli [Ethnogenesis and Biosphere of the Earth]. Moscow, Tanais Di-Dik, 638.

Istoriiai kul'tura orochei. Istoriko-etnograficheskie ocherki. Pod. red. Turaeva V.A. [History and Culture of the Orochis. Historico-Ethnographic Notes. Ed. by V.A. Turaev] (2001). Saint-Petersburg, Nauka RAN, 169.

Jung, C.G. (1991). Psikhologiia i religiia. Arkhetip i simvol [Psychology and Religion. Archetype and Symbol]. Moscow, Renessans, 94.

Krupnik, I.I. (1998). Arkticheskaia etnologiia. Modeli traditsionnogo prirodopol'zovaniia morskikh okhotnikov i olenevodov Severnoi Evrazii [Arctic Ethnology. Models of Traditional Environmental Management of Chasers and Reindeer Herders of North Eurasia]. Moscow, Nauka, 276.

Markarian, E.S. (1983). Kul'tura zhizneobespecheniia ietnos. Opyt etnokul'turnogo issledovaniia (na primere armianskoj kul'tury) [Culture of Subsistence and Ethnos. An Experience of Ethnocultural Research (based on Armenian Culture)]. Erevan, Iz-vo AN Armianskoi SSR, 36.

Orlova, E.A. (2002). Sociokul'turnoe prostranstvo obydennoizhizni: metodicheskoe posobie po kursu «Kul'turnaia antropologiia» [Sociocultural Space of Everyday Life. Study Guide for the Course of Cultural Anthropology]. Moscow, GASK, 104.

Podmaskin, V.V. (1990). O proiskhozhdenii nekotorykh udegeiskikh i orochskikh gidronimov [On the Origin of Some Udege and OrochHydronyms], In Istoricheskie nazvaniia - pamiatniki kul'tury: Materialy nauchno-prakticheskoi konferentsii [Historical Names - Cultural Artefacts. Proceedings of the Research-to-Practice Conference]. Vladivostok, 60.

Pushkarev, L.N. (1995). Chto takoe mentalitet? [What is mentality?], In Otechestvennaia istoriia [National History], 3.

Reshetov, A.M. (1983). Etnopsikhologiia i smezhnye nauki [Ethnopsychology and Related Sciences], In Sovetskaia etnografiia [Soviet Ethnography], 4, 12-14. 


\section{Теоретические подходы}

к изучению жизнедеятельности этноса

\section{О.А. Ильяшевич}

Хабаровский государственньй институт культурь Россия, 680045, Хабаровск, ул. Краснореченская, 112

В предлагаемой статье автор рассматривает жизнедеятельность этноса как особую категорию в современном культурологическом и этнологическом знании. Под жизнедеятельностью такой социальной общности, как этнос, автор понимает социально-технологический комплекс культурных процессов, который направлен на поддержание относительной целостности связей внутри общности, а также на целесообразное изменение и преобразование соииокультурного пространства в интересах функционирования общности. Анализ различных подходов к определению сущностного своеобразия этноса и этнической культуры позволяет автору рассмотреть жизнедеятельность этноса как комплекс процессов, обеспечивающих жизнестойкость, высокий адаптивный и креативный потенииал этнической культуры. Основанием жизнедеятельности этноса служит непрерывность культурной традиции, особенно значимая для определения характера взаимодействия с природной средой.

Ключевые слова: этнос, жизнедеятельность, жизнеобеспечение, образ жизни, этническая ментальность, этнокультура.

Научная специальность: 24.00.00 - культурология. 